\title{
Factors That Influencing Adoption of Internet Banking in Malaysia
}

\author{
Mathavi Massilamany ${ }^{1} \&$ Dineswary Nadarajan ${ }^{1}$ \\ ${ }^{1}$ SEGi University, Malaysia \\ Correspondence: Mathavi Massilamany, SEGi University, Malaysia. E-mail: mahiswaran@gmail.com
}

Received: January 20, 2017

Accepted: January 30, 2017 Online Published: February 22, 2017

doi:10.5539/ijbm.v12n3p126

URL: https://doi.org/10.5539/ijbm.v12n3p126

\begin{abstract}
This present studies to examine the factors that influencing adoption of internet banking in Malaysia. This study consists of one dependent variable (internet banking adoption) and four independent variables (knowledge and self-efficacy, trust, security and convenience). By using a quantitative research, a simple random sampling technique is used to distribute survey questionnaires to sample size of 200 respondents around Malaysia. The result was concluded as two (2) hypotheses were supported and two (2) hypotheses were not supported. The result shown that knowledge and self-efficacy and trust do influence adoption of internet banking in Malaysia. Meanwhile, there is insufficient evidence to support that security and convenience do influence adoption of internet banking in Malaysia. Bankers and consumers may refer to this research so that they can improve competitive advantage and consumers are able to understand better about internet banking.
\end{abstract}

Keywords: Internet banking adoption, knowledge and self- efficacy, trust, security and convenience

\section{Introduction}

Internet banking provides consumers a fast and convenient method to undergo many banking transactions at anytime and anywhere either from home or office. This is because it is 24 hours a day and 7 days a week services that been provided from internet banking. Consumers can save time for travel and line in queues to pay bills or to access other banking services. Unfortunately, despite of the numerous benefits from internet banking, the acceptance of internet banking in Malaysia is relatively low compared to Europe (Statista, 2015). Generally, Europe has leads in internet banking technology and usage. Hence, more efforts are needed to investigate the factors that influencing Malaysian consumers to adopt internet banking.

Many theories have suggested numerous potential influences on consumer adoption in internet banking. The theories include behavior of consumer choice of mass media, adoption of online service, costs of switching services and internet banking adoption. However, there were not much research has been done in Malaysia regarding adoption of internet banking among users. Hence, the actual reasons that influencing consumers adoption in internet banking in Malaysia will be find out in this research. The key question is "What are the factors that influencing adoption of internet banking in Malaysia?".

\subsection{Research Objectives}

1. To investigate the relationship between knowledge and self-efficacy and adoption of internet banking in Malaysia.

2. To investigate the relationship between trust and adoption of internet banking in Malaysia.

3. To investigate the relationship between security and adoption of internet banking in Malaysia.

4. To investigate the relationship between convenience and adoption of internet banking in Malaysia.

\section{Literature Review}

\subsection{Internet Banking Adoption}

There are many studies that have been done until today to determine the factors influencing internet adoption by using different theories and models. In Malaysia, Ainin, C.H, \& Wei (2005) studied the information, legal statement, ease of use aesthetic effects, performance and other elements of bank that provide internet banking by adapting a website evaluation model. The study found out there is positive significant relationship between age, job level and monthly gross income with internet banking adoption among Klang Valley adopters. In other hand, there are negative significant relationship between gender, marital status, ethnic group or education with internet 
banking adoption among Klang Valley adopters. The study also found out that the influence from friends, colleagues and peers give a highest percentage (53\%) on the internet banking adoption decision. In addition, trust is the most important factors that influences the intention of current users to continue using internet banking services. This has been studied by Tat \& Nor(2008) where the findings shows that three significant predictors included trust, compatibility and ease of use were accounted $56 \%$ variance of intention to continue using internet banking services which trust was found out to have the strongest significant relationship with the influence on the intention to keep using internet banking services.

In the recent years, there is an increase in number of researches regarding internet banking adoption around the world. For example, there are quite a number of study done such as Yu, Balaji, \& Khong (2015), Sikdar, Kumar, \& Makkad (2015) and Tat \& Nor(2008). Most of the studies investigate the effect of trust on the influence of adoption in internet banking among consumer. Meanwhile, some of it agrees that accessibility (Wai-Ching Poon, 2007), security (Shanmugam, Wang, Bugshan, \& Hajli, 2015), perceived usefulness(Jaruwachirathanakul \& Fink, 2015)and ATM users (Giordani, Floros, \& Judge, 2014) also shows significant relationship with internet banking adoption among consumers.

\subsection{Knowledge and Self-efficacy}

Consumers should have a familiarity with computers and must have skills on using web browsers because internet act as a key medium for internet banking services (Lee, Kwon, \& Schumann, 2005). Consumers that have more knowledge on computer technologies may easily adopt internet banking and enhance their efficiency in the use of internet banking. In addition, they do not need to spend more time and money in order to learn how to use internet banking (Kim, Widdows, \& Yilmazer, 2005). According to Harrison, Onyia, \& Stephen K. Tagg(2014), a customer who has prior experience on using computer and the Internet and aware of the benefits can be received would most likely to adopt internet banking. To support the statement, a research by Clemes, $\mathrm{Gan}, \& \mathrm{Du}(2012)$ states that customers who are familiar with internet environment enhance the internet banking acceptance by individuals who have prior experience on using Internet. Moreover, lack in knowledge about the internet banking service is known as the third reason that been used often by the non-users of internet banking (Gerrard, Cunnigham, \& F.Devlin, 2006). This is due to unawareness of on what is the need to become an internet banking user as well as unawareness of the computer skills level required in operating internet banking services.

Older consumers always have a same problem where they are lacking in computer skills and there is a need to get education on the internet basis knowledge in order to use internet banking. In general, users of internet whom usually express their confidence in their capability of using Internet is a confidence where obtained from many experiences that have positive results and the familiarity with this channel which is Internet (Lichtenstein \& Williamson, 2006). Moreover, an ability of an individual to have a skill in using mobile will improve his enjoyment and usefulness which have a positively effect on behavioral intention to use mobile services ( $\mathrm{Lu} \&$ Philip Yu-Jen Su, 2009). Based on the above discussion, it can be seen that there is a significant relationship between knowledge and self-efficacy and internet banking adoption. Hence, it is included in this research conceptual framework.

\subsection{Trust}

In the context of electronic commerce, trust receives the biggest attention since there is high risk and uncertainty in online transactions. Trust has been found to become a factor that affecting adoption of user in many services such as online news services (Chen \& Corkindale, 2008), internet banking (Flavián, Guinalíu, \& Torres, 2005) and health websites (Fisher, Burstein, Lynch, \& Lazarenko, 2008). Trust consists of initial and continuance trust. Initial trust relatively has relationship with behavior of the user in the first stage of trust development. Many factors have been found to affect initial trust. The first category of factors is related to the website. In order to build the initial trust, most of the users who are lacking in prior experience will depend on their perception of quality of the website (Lowry, Vance, Moody, Beckman, \& Read, 2008). In addition, another factor that has been found that can affect initial trust in health infomediaries is the quality of the information (Zahedi \& Jaeki Song, 2008). Moreover, consumer is related to the second category of factors. Tendency of trust has a significant effect on initial trust according to Li, Hess, \& Valacich (2008), but this effect will lessen bit by bit with experience increases accordance to Zahedi\& Jaeki Song (2008).However, the third category of factors is related with company such as corporate image (Flavián, Guinalíu, \& Torres, 2005). Third parties are known as the fourth category of factors. Trust may be transferred to third parties such as online vendors by the consumers. Initial trust of online consumers can also been affected by brand association (Delgado-Ballester \& Hernández-Espallardo, 2008). 


\subsection{Security}

Security could be a factor to not adopting internet banking if there is lacking in security ((Rajesh Kumar Srivastava, 2007). Security considers as one of the key factor that can change customers' perceptions on online banking services adoption. Mostly, customer does not has trust on the web because there are few deficiencies in its security mechanism. Hence, in order to improve online banking development, problem regarding security need to be solved since most of the customers have a high concern on risk while using online banking to do their financial transactions (Ming-Chi Lee, 2009). Furthermore, potential users in online banking services adoption are conscious that safety and security of the technologies are not good which can lead to mistake and errors in or to accomplish the transaction. So, they are least likely to use online banking services.

Security is a very concern issue in order to change customers' perception on online banking services from negative to positive. This is due to relationship between securities and online banking services adoption is positively related (Guangying Hua, 2009). Because of this, bankers need to lessen frauds and risks in online banking hence all bank users can increase their confidence and retention on adopting online banking services. Thus, security in online banking need to be high and risk on using online banking need to be lowered in order to change customers' perception on online banking as a secure and accessible delivery channel. As to support the statement, Mukhtar(2015) states that security in online banking services is important factor in order to change customers' perception on internet banking from negative to positive. This is because if there is no security system during transactions process, it will be hard for the customers to give trust to the service providers.

The number of security will always increasing due to higher demand on data access from consumers. There are few security control that has been studied which are authentication control, privacy control and non-repudiation control to enhance security in internet banking services (Ray, Ow, \& Sung S. Kim, 2011). To lead a better security, various techniques of security can be used in implementation of these types of security controls.Based on the above discussion, it can be seen that there is a relation between security and internet banking adoption. Hence, it is included in this research conceptual framework.

\subsection{Convenience}

Convenience from lifestyle perspective has been defined as does not need to travel, privacy safety and does not need to wait (Lichtenstein \& Williamson, 2006). Furthermore, most of the total consumers agree or strongly agree that internet is convenient since internet banking provides many advantages such as no waiting in line in bank and it can be done wherever and whenever (Singhal \& Padhmanabhan, 2008). Meanwhile a study by Wan, Luk, \& Chow (2005) cites that even though internet banking adoption is most affected by convenience, but it cannot compete with ATM because ATM is the only channel that enable withdrawal of cash at anytime and does not require customer to have an access to computer facilities. In addition, Lee, Kwon, \& Schumann (2005) also found convenience as key factor on determining users' intention in adopting internet banking services. At the same time, another study by Abdul Kabeer Kazi (2013), the studies in Pakistan shows that a higher education level of students has more intention in adopting internet banking because of convenience. This is because students already have access to the Internet so their optional is to internet banking rather than conventional systems since most of their times are spent on studies thus they have no time to practice conventional systems. Moreover, convenience means people can pays their bills, account balance check, fund transfer and other services through online banking at anywhere and anytime. Laukkanen \& Lauronen (2005) states that convenience is defined as the ability to check account movements or transactions wherever and whenever the consumer wants to. Lichtenstein \& Williamson (2006) also stressed that save of time and 24 hours 7 days a week access are key aspects of the convenience in online banking services. In this aspects of convenience reflect 'ease of use' and act as necessary role in online banking adoption. Furthermore, serviceability has a positive significant with satisfaction of customer in adopting internet banking service. This means customers do think about convenience, comfortable and empathy before they want to adopt internet banking services. From those three factors, convenience and comfortable show impact on satisfaction of customer (Ma, 2012).

Based on the above discussion, it can be seen that there is a positively relation between convenience and internet banking adoption. Hence, it is included in this research conceptual framework. 


\section{Data Analysis and Discussion of Findings}

\subsection{Correlation Analysis}

\begin{tabular}{lllllll}
\hline Correlations & & & & & \\
& & INT_BANK & KNOW_SELF & TRU_ST & SECURI_TY & CONVE_NIENCE \\
\hline INT_BANK & Pearson Correlation & 1 & $.553^{* *}$ & $.367^{* *}$ & $.469^{* *}$ & $.462^{* *}$ \\
& Sig. (2-tailed) & & .000 & .000 & .000 & .000 \\
& $\mathrm{~N}$ & 200 & 200 & 200 & 200 & 200 \\
KNOW_SELF & Pearson Correlation & $.553^{* *}$ & 1 & $.311^{* *}$ & $.520^{* *}$ & $.608^{* *}$ \\
& Sig. (2-tailed) & .000 & & .000 & .000 & .000 \\
& $\mathrm{~N}$ & 200 & 200 & 200 & 200 & 200 \\
TRU_ST & Pearson Correlation & $.367^{* *}$ & $.311^{* *}$ & 1 & $.545^{* *}$ & $.315^{* *}$ \\
& Sig. (2-tailed) & .000 & .000 & & .000 & .000 \\
& $\mathrm{~N}$ & 200 & 200 & 200 & 200 & 200 \\
SECURI_TY & Pearson Correlation & $.469^{* *}$ & $.520^{* *}$ & $.545^{* *}$ & 1 & $.623^{* *}$ \\
& Sig. (2-tailed) & .000 & .000 & .000 & & .000 \\
& $\mathrm{~N}$ & 200 & 200 & 200 & 200 & 200 \\
CONVE_NIENCE & Pearson Correlation & $.462^{* *}$ & $.608^{* *}$ & $.315^{* *}$ & $.623^{* *}$ & 1 \\
& Sig. (2-tailed) & .000 & .000 & .000 & .000 & 200 \\
& $\mathrm{~N}$ & 200 & 200 & 200 & 200 & \\
**. Correlation is significant at the 0.01 level (2-tailed). & & & & \\
\hline
\end{tabular}

According to Hinkle, Wiersma, \& Jurs(2003), a correlation between \pm 0.00 to \pm 0.30 indicates little correlation, a correlation is in range of \pm 0.30 to \pm 0.50 is low, \pm 0.50 to \pm 0.70 is moderate, \pm 0.70 to \pm 0.90 is high and \pm 0.90 to \pm 1.00 is very high.

Hypothesis 1: There is a positively relation between knowledge and self-efficacy and internet banking adoption.

According to correlation table above, the correlation coefficient is 0.553 shows that there is apositive relationship between knowledge and self-efficacy and internet banking adoption. In addition, the correlation coefficient falls under the range of \pm 0.50 to \pm 0.70 which indicates the relationship between these two variables is moderate. Furthermore, the p-value for this hypothesis is less than 0.05 which are 0.000 at the significance level of $5 \%$. Thus, it resulted in $\mathrm{H}_{0}$ is rejected and $\mathrm{H}_{1}$ is accepted. Hence, it shows that there is a significant positive relationship between knowledge and self-efficacy and internet banking adoption.

\section{Hypothesis 2: There is a positively relation between trust and internet banking adoption.}

The correlation coefficient is 0.367 shows that there is a positive relationship between trust and internet banking adoption. In addition, the correlation coefficient falls under the range of \pm 0.30 to \pm 0.50 which indicates the relationship between these two variables is low. Furthermore, the p-value for this hypothesis is less than 0.05 which are 0.000 at the significance level of $5 \%$. Thus, it resulted in $\mathrm{H}_{0}$ is rejected and $\mathrm{H}_{1}$ is accepted. Hence, it shows that there is a significant positive relationship between trust and internet banking adoption.

\section{Hypothesis 3: There is a positively relation between security and internet banking adoption.}

According to the correlation coefficient is 0.469 shows that there is a positive relationship between security and internet banking adoption. In addition, the correlation coefficient falls under the range of \pm 0.30 to \pm 0.50 which indicates the relationship between these two variables is low. Furthermore, the p-value for this hypothesis is less than 0.05 which are 0.000 at the significance level of $5 \% . \mathrm{H}_{0}$ is rejected and $\mathrm{H}_{1}$ is accepted. Hence, it shows that there is a significant positive relationship between security and internet banking adoption.

\section{Hypothesis 4: There is a positively relation between convenience and internet banking adoption.}

The correlation coefficient is 0.462 shows that there is a positive relationship between convenience and internet banking adoption. In addition, the correlation coefficient falls under the range of \pm 0.30 to \pm 0.50 which indicates the relationship between these two variables is low. Furthermore, the p-value for this hypothesis is less than 0.05 which are 0.000 at the significance level of $5 \%$. Thus, it resulted in $\mathrm{H}_{0}$ is rejected and $\mathrm{H}_{1}$ is accepted. Hence, it shows that there is a significant positive relationship between convenience and internet banking adoption. 


\subsection{Multiple Regression Analysis}

Independent variable for this study is more than one, hence multiple regression is used in order to determine overall effect of all the independent variables (knowledge and self-efficacy, trust, security and convenience) on dependent variable (internet banking adoption). $\mathrm{R}^{2}$ value is used to determine the variation on dependent variable towards all the independent variables. However, Multiple $\mathrm{R}$ value, $(\mathrm{R})$ is to measure the degree of relationship with all independent variables and dependent variable (Gujarati \& Porter, 2009). Furthermore, the overall significance of the multiple regression is indicated by the Analysis of Variance (ANOVA) and unstandardized coefficient $B$ value is used to represent the regression coefficients of each independent variable.

\begin{tabular}{|c|c|c|c|c|c|}
\hline \multicolumn{6}{|c|}{ Model Summary } \\
\hline \multirow[b]{2}{*}{ Model } & \multirow[b]{2}{*}{$\mathrm{R}$} & \multirow[b]{2}{*}{ R Square } & \multirow[b]{2}{*}{ Adjusted R Square } & \multicolumn{2}{|c|}{ Std. Error of the } \\
\hline & & & & Estimate & Durbin-Watson \\
\hline 1 & $.609^{\mathrm{a}}$ & .371 & .358 & .50300 & 1.800 \\
\hline
\end{tabular}

Based on the model summary, $\mathrm{R}=0.609$ indicates that high correlation between all the four variables (knowledge and self-efficacy, trust, security and convenience) on internet banking adoption. R-square value is 0.371 shows that $37.1 \%$ of total variation on internet banking adoption can be explained by all the four independent variables. The unexplained residual are the remaining variation which is $62.9 \%(100 \%-37.1 \%)$. Hence, it is concluded that this study does not include few significant factors that influencing internet banking adoption. In addition, Durbin-Watson value is 1.800 which fall in the range of the acceptable threshold of 1 and 3 indicates there is no autocorrelation among the residuals.

\begin{tabular}{lllllll}
\hline $\begin{array}{llllll}\text { ANOVA }^{\mathbf{a}} \\
\text { Model }\end{array}$ & & Sum of Squares & df & Mean Square & F & Sig. \\
\hline 1 & Regression & 29.096 & 4 & 7.274 & 28.750 & $.000^{\mathbf{b}}$ \\
& Residual & 49.337 & 195 & .253 & & \\
& Total & 78.432 & 199 & & & \\
\hline
\end{tabular}

a. Dependent Variable: INT_BANK;

b. Predictors: (Constant), CONVE_NIENCE, TRU_ST, KNOW_SELF, SECURI_TY.

F-value is significant at 18.750 and the p-value is below alpha of 0.05 which is 0.000 . This shows that multiple regression model is significance of the $5 \%$ level of significance and the model is fit to explain the relationship between internet banking adoption and knowledge and self-efficacy, trust, security and convenience.

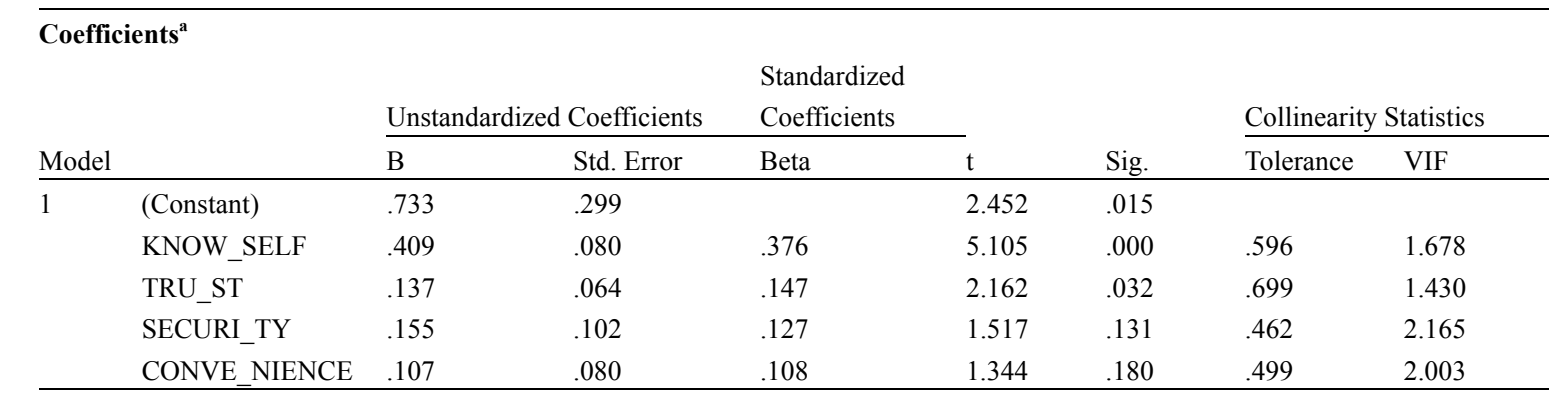

a. Dependent Variable: INT_BANK.

Based on the coefficient table above, the variance inflation factor (VIF) value for independent variables (knowledge and self-efficacy, trust, security and convenience) are 1.678, 1.430, 2.165 and 2.003 respectively which are below than 10. This indicates there is no multicollinearity. In addition, the significant value must be less than 0.05 in order for the hypothesis to be accepted or not supported. There are two variables are supported 
which are knowledge and self-efficacy $(\mathrm{Sig}=0.000)$ and trust $(\mathrm{Sig}=0.032)$. However, there are two variables are not supported which are security $(\mathrm{Sig}=0.131)$ and convenience $(\mathrm{Sig}=0.180)$ as the significance value is more than 0.05. As for result, there is an impact on knowledge and self-efficacy and trust towards internet banking adoption. Meanwhile, there is no impact between security and convenience towards internet banking adoption.

The result shows that knowledge and self-efficacy has highest contribution towards internet banking adoption as both unstandardized coefficient B value and standardized coefficient are the highest among others. This can be interpreted as for unstandardized coefficient B value for knowledge and self-efficacy increased in 1 unit, internet banking adoption will increased by 0.409 , holding other variables are constant. Meanwhile, as for standardized coefficient Beta value, is interpreted when 1 standard deviation increase in knowledge and self-efficacy, the standard deviation of internet banking adoption will increased by 0.376 . The rank is followed by security, trust and convenience based on the unstandardized coefficient $B$ value.

By using the unstandardized coefficient $\mathrm{B}$ value from the table, equation that can describe the relationship between independent variables (knowledge and self-efficacy, trust, security and convenience) and internet banking adoption is as followed:

\begin{tabular}{|c|c|c|c|c|}
\hline \multicolumn{5}{|c|}{$\mathrm{DV}=$ Constant $+\beta_{1} x_{1}+\beta_{2} x_{2}+\beta_{3} x_{3}+\beta_{4} x_{4}+$ error } \\
\hline \multicolumn{5}{|c|}{$\begin{array}{c}\text { Internet Banking Adoption }= \\
\text { Constant }+\beta_{1}(\text { Knowledge and Self }- \text { efficacy })+\beta_{2}(\text { Trust })+\beta_{3}(\text { Security })+\beta_{4}(\text { Convenience }) \\
\text { error }\end{array}$} \\
\hline \multicolumn{5}{|c|}{$\begin{aligned} \text { Internet Banking Adoption }= & 0.733+0.409(\text { Knowledge and Self }- \text { efficacy })+0.137(\text { Trust })+ \\
& 0.155(\text { Security })+0.107(\text { Convenience })\end{aligned}$} \\
\hline HYPOTHESES & HYPOTHESIS STATEMENT & SIG. & $\begin{array}{l}\text { GRADIENT } \\
(\text { Beta, } \beta)\end{array}$ & RESULT \\
\hline $\mathrm{H} 1$ & $\begin{array}{l}\text { There is a positively relation between } \\
\text { knowledge and self-efficacy and internet } \\
\text { banking adoption. }\end{array}$ & 0.000 & 0.376 & $\begin{array}{l}\text { Hypothesis is } \\
\text { supported }\end{array}$ \\
\hline $\mathrm{H} 2$ & $\begin{array}{l}\text { There is a positively relation between trust } \\
\text { and internet banking adoption. }\end{array}$ & 0.032 & 0.147 & $\begin{array}{l}\text { Hypothesis is } \\
\text { supported }\end{array}$ \\
\hline $\mathrm{H} 3$ & $\begin{array}{l}\text { There is a positively relation between } \\
\text { security and internet banking adoption. }\end{array}$ & 0.131 & 0.127 & $\begin{array}{l}\text { Hypothesis is } \\
\text { not supported }\end{array}$ \\
\hline $\mathrm{H} 4$ & $\begin{array}{l}\text { There is a positively relation between } \\
\text { convenience and internet banking adoption. }\end{array}$ & 0.180 & 0.180 & $\begin{array}{l}\text { Hypothesis is } \\
\text { not supported }\end{array}$ \\
\hline
\end{tabular}

As a summary the significant value and Beta value for all independent variables. Based from the table above, there are two hypotheses of independent variables (knowledge and self-efficacy and trust) are supported. But, the hypotheses for remaining independent variables (security and convenience) are not supported. This indicates H1 and $\mathrm{H} 2$ are supported whereas $\mathrm{H} 3$ and $\mathrm{H} 4$ are not supported.

\section{Conclusion}

This research show that knowledge and self-efficacy, trust, security and convenience have a relationship with the internet banking adoption. According to the Pearson correlation test, all independent variable (knowledge and self-efficacy, trust, security and convenience) have positive relationship to internet banking adoption.

Based on the result, knowledge and self-efficacy has the strongest contribution towards internet banking adoption compared to other variables. In new era, most of the internet users have an adequate computer skills and have skills on using the Internet to adopt internet banking. Moreover, Internet users are easily to learn to use internet banking as they already have knowledge and self-efficacy regarding the similar technology before.

Security has been found to the second strongest contribution to internet banking adoption since the user feel more confident about the security aspects of internet banking as there are many safeguards has developed with the current technology. Furthermore, most of the Internet users do not like their personal information been 
uncovered when dealing with internet banking. With current technology, internet banking is able to keep Internet users' personal details secured by enhancing a security program on the website.

After that, trust also has high contribution to internet banking adoption because bank offers enough security protection in order to prevent unauthorized intrusion so that the Internet users are comfortable with conducting internet banking for their personal business. However, some of them feel that internet banking are not as assurance as traditional banking. They do not belief that bank is able to recover their money if online bank account been hacked and money was stolen. Hence, bank should hire a technician to inspect the system from time to time to avoid any system malfunction to occur.

Lastly, convenience has the least contribution to internet banking .The Internet users do not like to waste time for managing low performance of internet banking service when breakdown of system servers occurs which can cause inconveniences. Hence, less consumers would adopt internet banking. So, bank should ensure that their online websites are free from breakdowns at any time.

\section{References}

Abdul, K. K. (2013). An Empirical Study of Factors Influencing Adoption of Internet Banking among Students of Higher Education: Evidence from Pakistan. Journal of Internet Banking and Commerce, 18(2), 1-13.

Ainin, C. H. L., \& Wee. (2005). Prospects and Challenges of E-banking in Malaysia. The Electronic Journal on Information Systems in Developing Countries, 22(2), 1-11.

Asfour, H. K., \& Haddad, S. I. (2014). The impact of Mobile Banking on enhancing customers' E-satisfaction: An empirical study on commercial banks in Jordan. International Business Research, 7(10), 145-169. https://doi.org/10.5539/ibr.v7n10p145

Chen, Y. H. H., \& Corkindale, D. (2008). Towards an understanding of the behavioral intention to use online news services: An exploratory study. Internet Research, 18(3), 286-312. https://doi.org/10.1108/10662240810883326

Chinomona, R., \& Sandada, M. (2013). Customer Satisfaction, Trust and Loyalty as Predictors of Customer Intention to Re-Purchase South African Retailing Industry. Mediterranean Journal of Social Sciences, 4(14), 437-446. https://doi.org/10.5901/mjss.2013.v4n14p437

Delgado-Ballester, E., \& Hernández-Espallardo, M. (2008). Effect of Brand Associations on Consumer Reactions to Unknown On-Line Brands. International Journal of Electronic Commerce, 12(3), 81-113. https://doi.org/10.2753/JEC1086-4415120305

Enders, A., König, A., Jelassi, T., \& Hungenberg, H. (2006). The relativity of disruption: E-banking as a sustaining innovation in the banking industry. Journal of Electronic Commerce Research, 7(2), 67-77.

Fisher, J., Burstein, F., Lynch, K., \& Lazarenko, K. (2008). Usability + usefulness = trust”: An exploratory study of Australian health web sites. Internet Research, 18(5), 477-498. https://doi.org/10.1108/10662240810912747

Flavián, C., Guinalíu, M., \& Torres, E. (2005). The influence of corporate image on consumer trust: A comparative analysis in traditional versus internet banking. Internet Research, 15(4), 447-470. https://doi.org/10.1108/10662240510615191

Fock, S. T., \& Koh, H. C. (2006). Conceptualization of Trust and Commitment:Understanding the Relationships Between Trust and Commitment and the Willingness to Try Internet Banking Services. International Journal of Business and Information, 1(2), 194-208.

Giordani, G., Floros, C., \& Judge, G. (2014). Economic investigation of internet banking adoption in Greece. Journal of Economic Studies, 41(4), 586-600. https://doi.org/10.1108/JES-04-2011-0042

Grabner-Kra"uter, S., \& Faullant, R. (2008). Consumer acceptance of internet banking: the influence of internet trust. International Journal of Bank Marketing, 26(7), 483-504. https://doi.org/10.1108/02652320810913855

Guangying, H. (2009). An Experimental Investigation of Online Banking Adoption in China. Journal of Internet Banking and Commerce, 14(1), 1-12.

Gunasekaran, A., \& Ngai, E. (2005). E - commerce in Hong Kong: an empirical perspective and analysis. Internet Research, 15(2), 141-159. https://doi.org/10.1108/10662240510590333 
Harrison, T. S., Onyia, O. P., \& Stephen K. Tagg. (2014). Towards a universal model of internet banking adoption: initial conceptualization. International Journal of Bank Marketing, 32(7), 647-687. https://doi.org/10.1108/IJBM-06-2013-0056

Hernandez, J. M., \& Mazzon, J. A. (2007). Adoption of internet banking: Proposition and implementation of an integrated methodology approach. International Journal of Bank Marketing, 25(2), 72-88. https://doi.org/10.1108/02652320710728410

Jaruwachirathanakul, B., \& Fink, D. (2015). Internet banking adoption strategies for a developing country: The case of Thailand. Internet Research, 15(3), 295-311. https://doi.org/10.1108/10662240510602708

Kim, B. M., Widdows, R., \& Yilmazer, T. (2005). The Determinants of Consumers' Adoption of Internet Banking. Proceedings of the Consumer Behavior and Payment Choice 2005 Conference, Boston, MA.

Laforet, S., \& Li, X. (2005). Consumers' attitudes towards online and mobile banking in China. International Journal of Bank Marketing, 23(5), 362-380. https://doi.org/10.1108/02652320510629250

Laukkanen, T., \& Lauronen, J. (2005). Consumer value creation in mobile banking services. International Journal of Mobile Communications, 3(4), 325-338. https://doi.org/10.1504/IJMC.2005.007021

Lee, E. J., Kwon, K. N., \& Schumann, D. W. (2005). Segmenting the non-adopter category in the diffusion of internet banking. International Journal of Bank Marketing, 23(5), 414-437. https://doi.org/10.1108/02652320510612483

Li, X., Hess, T. J., \& Valacich, J. S. (2008). Why do we trust new technology? A study of initial trust formation with organizational information systems. The Journal of Strategic Information Systems, 17, 39-71. https://doi.org/10.1016/j.jsis.2008.01.001

Lichtenstein, S., \& Williamson, K. (2006). Understanding Consumer Adoption of Internet Banking: An Interpretive Study in Australian Banking Context. Journal of Electronic Commerce Research, 7(2), 50-66.

Lowry, P. B., Vance, A., Moody, G., Beckman, B., \& Read, A. (2008). Explaining and Predicting the Impact of Branding Alliances and Web Site Quality on Initial Consumer Trust of E-Commerce Web Sites. Journal of Management Information Systems, 24(4), 201-227. https://doi.org/10.2753/MIS0742-1222240408

Lu, H. P., \& Philip Yu-Jen, S. (2009). Factors affecting purchase intention on mobile shopping web sites. Internet Research, 19(4), 442-458. https://doi.org/10.1108/10662240910981399

Ma, Z. (2012). Assessing serviceability and reliability to affect customer satisfaction of Internet Banking. Journal of Software, 7(7), 1601-1608. https://doi.org/10.4304/jsw.7.7.1601-1608

Ming-Chi, L. (2009). Factors influencing the adoption of internet banking: An integration of TAM and TPB with perceived risk and perceived benefit. Electronic Commerce Research and Applications, 8(3), 130-141. https://doi.org/10.1016/j.elerap.2008.11.006

Mukhtar, M. (2015). Perceptions of UK Based Customers toward Internet Banking in the United Kingdom. Journal of Internet Banking and Commerce, 20(1), 1-38.

Nor, K. M., \& Pearson, J. M. (2007). The Influence of Trust on Internet Banking Acceptance. Journal of Internet Banking and Commerce, 12(2), 1-10.

Ong, T. S., Hong, Y. H., The, B. H., Soh, P. C. H., \& Tan, C. P. (2014). Factors That Affect the Adoption of Internet Banking in Malaysia. International Business Management, 8(2), 55-63.

Popoola, N. F., \& Razib, M. (2014). Strategic Approach to Build Customers Trust in Adoption of. Journal of Internet Banking and Commerce, 20(1), 1-14.

Rajesh, K. S. (2007). Customer's perception on usage of Internet Banking. Innovative Marketing, 3(4), 67-73.

Ray, S., Ow, T., \& Sung S. Kim. (2011). Security assurance: how online service providers can influence security control perceptions and gain trust. Decision Sciences Journal, 42(2), 391-412. https://doi.org/10.1111/j.1540-5915.2011.00316.x

Roca, J. C., García, J. J., \& Vega, J. J. (2009). The importance of perceived trust,security and privacy in online trading systems. Information Management \& Computer Security, 17(2), 96-113. https://doi.org/10.1108/09685220910963983

Shanmugam, M., Wang, Y. Y., Bugshan, H., \& Hajli, N. (2015). Understanding customer perceptions of internet banking: the case of the UK. Journal of Enterprise Information Management, 28(5), 622-636. https://doi.org/10.1108/JEIM-08-2014-0081 
Sikdar, P., Kumar, A., \& Makkad, M. (2015). Online Banking Adoption. International Journal of Bank Marketing, 33(6), 760-785. https://doi.org/10.1108/IJBM-11-2014-0161

Singhal, D., \& Padhmanabhan, V. (2008). A Study on Customer Perception Towards Internet Banking: Identifying Major Contributing Factors. The Journal of Nepalese Business Studies, 5(1), 101-111. https://doi.org/10.3126/jnbs.v5i1.2088

Statista. (2015). Online banking penetration in the European Union (EU28) from 2007 to 2014. Retrieved from Statista: http://www.statista.com/statistics/380803/online-banking-penetration-in-the-eu/

Tat, H. H., \& Nor, K. M. (2008). Predictors of Intention To Continue Using Internet Banking Services: An Empirical Study of Current Users. International Journal of Business and Information, 3(2), 233-244.

Wai-Ching Poon. (2007). Users' adoption of e-banking services: the Malaysian perspective. Journal of Business \& Industrial Marketing, 23(1), 59-69. https://doi.org/10.1108/08858620810841498

Wan, W. W., Luk, C. L., \& Chow, C. W. (2005). Customers' adoption of banking channels in Hong Kong. International Journal of Bank Marketing, 23(3), 255-272. https://doi.org/10.1108/02652320510591711

Yu, P. L., Balaji, M. S., \& Khong, K. W. (2015). Building trust in internet banking: a trustworthiness perspective. Industrial Management \& Data Systems, 115(2), 235-252. https://doi.org/10.1108/IMDS-09-2014-0262

Zahedi, F., \& Jaeki, S. (2008). Dynamics of Trust Revision: Using Health Infomediaries. Journal of Management Information Systems, 24(4), 225-248. https://doi.org/10.2753/MIS0742-1222240409

\section{Copyrights}

Copyright for this article is retained by the author(s), with first publication rights granted to the journal.

This is an open-access article distributed under the terms and conditions of the Creative Commons Attribution license (http://creativecommons.org/licenses/by/4.0/). 